\title{
Congenital Isolated Adrenocorticotropic Hormone Deficiency
}

National Cancer Institute

\section{Source}

National Cancer Institute. Congenital Isolated Adrenocorticotropic Hormone Deficiency.

NCI Thesaurus. Code C120437.

Adrenocorticotropic hormone (ACTH) deficiency due to mutation(s) in the TBX19 gene. 